\title{
Oral candidiasis in HIV+ patients under treatment with protease inhibitors
}

\section{Andréa Lusvarghi Witzel(a) Fernando Ricardo Xavier da Silveira ${ }^{(b)}$ \\ Maria de Fátima Costa Pires(c) \\ Mônica Andrade Lotufo ${ }^{(d)}$}

\footnotetext{
(a) PhD, Professor; (b) PhD, Associate Professor - Department of Stomatology, School of Dentistry, University of São Paulo.

(c) PhD, Senior Researcher, Adolfo Lutz Institute, São Paulo.

(d) Professor, Dental School, Ibirapuera University.
}

\begin{abstract}
The purpose of this work was to evaluate the influence of Protease Inhibitors (PI) on the occurrence of oral candidiasis in $111 \mathrm{HIV+}$ patients under PI therapy (Group A). The controls consisted of 56 patients that were not using PI drugs (Group B) and 26 patients that were not using any drugs for HIV therapy (Group C). The patient's cd4 cell counts were taken in account for the correlations. One hundred and ninety three patients were evaluated. The PI did not affect the prevalence of oral candidiasis $(\mathrm{p}=0.158)$ or the frequency of C. albicans isolates $(\mathrm{p}=0.133)$. Patients with lower cd4 cell counts showed a higher frequency of C. albicans isolates $(\mathrm{p}=0.046)$ and a greater occurrence of oral candidiasis $(\mathrm{p}=0.036)$.
\end{abstract}

Descriptors: HIV; Candida albicans; Protease inhibitors.
Corresponding author:

Andréa Lusvarghi Witzel

R. Prado Valadares, 34, cs 7, Vila Polopoli

São Paulo - SP - Brazil

CEP: 05360-065

E-mail:gandrea@usp.br

Received for publication on Oct 31, 2007

Accepted for publication on Dec 10, 2007 


\section{Introduction}

Oral candidiasis is the most frequent mycosis produced by yeasts of the genus Candida, Candida albicans being the most important from the point of view of Public Health, although other species such as $C$. glabrata, C. parapsilosis, C. tropicalis, C. krusei and more recently C. dubliniensis have been isolated., ${ }^{1,2}$

In the acquired human immunodeficiency syndrome (AIDS), it is known that among the opportunist infections, oral candidiasis is the most frequent one, and C. albicans, among others, has been very important in assessing the evolutionary behavior of the disease. ${ }^{3}$ The first case of acquired human immunodeficiency syndrome (AIDS) related in the literature mentions that the patient was an oral candidiasis carrier. ${ }^{4}$

In human immunodeficiency virus (HIV+) patients, nonspecific oral immunity is reduced, contributing to the frequent appearance of candidiasis. $^{5,6}$

One of the most critical factors in the control of oral candidiasis in HIV+ patient is the resistance that the yeast develops to various drugs, notably some of the azolic derivatives. ${ }^{7}$

The introduction of protease inhibitor (PI) drugs on the marketplace for the treatment of AIDS has shown promising results in the clinical control of the disease, opening up a new perspective in the efforts made to enhance the systemic conditions of these patients. ${ }^{8}$

Many researchers attribute this improvement to the increase in the number of cd4 lymphocytes and to a reduction in viral load, which restores the patients' specific immunity, providing a decline in the incidence of opportunistic infections.

However, HIV virus carriers submitted to treatment with protease inhibitor drugs manifested a decline in oral candidiasis before there was an increase in the number of cd4 cells, which has led some authors to believe in the action of these drugs in the protease production mechanisms of C. albicans as well, leading to a change in its levels of activity. ${ }^{9}$

The Candida albicans strains isolated from $\mathrm{HIV}+$ patients were also those least susceptible to the azolic antifungal agents, specifically ketoconazol and fluconazol. ${ }^{10}$
The use of PI in the treatment of patients with HIV has diminished the complications related to AIDS, such as Kaposi's sarcoma, ${ }^{11}$ cryptosporosis ${ }^{12}$ and mucosal candidiasis. ${ }^{8,13,14}$

The PI drugs act directly on the proteases of the HIV, making the enzyme inactive, which favors the formation of non-infecting viral particles, promoting a reduction in viral load and an increase in $\mathrm{cd} 4$ cells, reestablishing the immune response. ${ }^{15}$

The antifungal effect of the PIs indinavir and saquinavir were demonstrated in vitro and in vivo..$^{10,16}$

The aim of this study was to compare the frequency of oral candidiasis in HIV+ patients under treatment with protease inhibitor and non protease inhibitor drugs.

\section{Material and Methods}

One hundred and ninety three HIV+ individuals, of both genders, who were having the number of cd4 cells assessed at the AIDs home, Zerbini Foundation, São Paulo, SP, Brazil, were selected for this study.

All the patients agreed to participate in the study by signing an informed consent form approved by the Research Ethics Committees of the School of Dentistry, University of São Paulo protocol n. 18/97), of the AIDS home and of the School of Medicine, University of São Paulo.

- Group A - 111 patients under treatment with protease inhibitors (PI) either associated with other drugs or not.

- Group B - 56 patients under treatment with other non protease inhibitors (NPI).

- Group C - 26 patients that were not using medication for the treatment of AIDS.

The clinical examination was carried out by a single examiner, a specialist in Stomatology, seeking to assess the presence of oral lesions compatible with candidiasis. In the cases in which the clinical diagnosis was positive, material was collected from the lesion for Cytologic testing, using a sterile swab, the smears being fixed in alcohol $(70 \%)$ immediately and forwarded to the laboratory for staining (Papanicolaou) and Microscopic examination (200 X). Cytologic positivity, combined with a clinical diagnosis, confirmed the presence of candidiasis. 
The variables adopted for the present study were as follows:

With regard to the presence of oral candidiasis:

0 - Without oral candidiasis

1 - Erythematous candidiasis carrier

2 - Pseudomembranous candidiasis carrier

The cd4 Cell Count was obtained by means of blood collection performed on the same day as the stomatological examination, and its results were afterwards noted on the patient's case history record. The cd4 count levels were as follows:

With regard to the number of cd4 cells:

1 - Number of cd $4 \geq 500 \mathrm{cel} / \mathrm{mm}^{3}$

$2-500 \mathrm{cel} / \mathrm{mm}^{3}>$ number of $\mathrm{cd} 4 \geq 200 \mathrm{cel} / \mathrm{mm}^{3}$

3 - Number of $\mathrm{cd} 4<200 \mathrm{cel} / \mathrm{mm}^{3}$

The material was collected by a single examiner from the oral mucosa using a sterile swab and was seeded, close to the lamp flame, in Sabouraud dextrose agar (Difco ${ }^{\circledR}$, Detroit, IL, USA), in addition to $100 \mu \mathrm{g} / \mathrm{ml}$ of Chloramphenicol (Park-Davis ${ }^{\circledR}$, São Paulo, SP, Brazil).

The plates were then incubated at $25^{\circ} \mathrm{C}$ for posterior yeast isolation. In case of negativity, they were maintained during 30 days.

The samples were identified according to the identification protocol of the Micology Center, Microbiology Department, Biomedical Sciences Institute, University of São Paulo, which included:

- Microculture on Slide (Corn-meal Agar in addition to Tween 80)

- Research of germination tubes

- Carbon hydrate fermentation test

- Assimilation tests for carbon and nitrogen sources

\section{Clinical record readings}

The patients' clinical records contained information on which medication was used, on the results of the cd4 cell counts done on the day of collection, as well as on the patients that did not use any anti-HIV medication.

The medication therapy administered to HIV virus carriers is very diversified. Generally, a combination of drugs (cocktail) is used. The presence or absence of proteinase inhibitor drugs was considered the delimitation for the groups setting. The drugs used at the time the patients' records were read considering the delimitation factor of the groups were: indinavir (Merk Sharp Dohme ${ }^{\circledR}$, São Paulo, SP, Brazil), nelfinavir (Roche ${ }^{\circledR}$, São Paulo, SP, Brazil), ritonavir (Abott ${ }^{\circledR}$, São Paulo, SP, Brazil) and saquinavir (Roche ${ }^{\circledR}$, São Paulo, SP, Brazil).

\section{Statistical analysis}

Descriptive analysis was carried out for all the study variables. The Chi-square test was used for the qualitative variables. For the quantitative variables, the homogeneity of the variances was tested by the Levene Test, and the normality of the data, by the Kolmogorov-Smirnov Test with the Lilliefors correction.

The variables that satisfied these two principles were submitted to parametric tests. In order to assess any differences between the medication groups, Analysis of Variance (ANOVA) was used, and when this was statistically significant, the HSD -Tukey (Honest Significant Difference) test was used to assess where the differences were.

\section{Results}

Of the 193 patients examined, $70.47 \%$ were men (136/193), with a mean age of 40 years, and $29.53 \%$ were women (57/193), with a mean age of 37 years.

Analysis of the characteristics of the isolates enabled C. albicans to be identified in 47.67\% (92/193) of the patients.

With regard to medication, the patients were divided into 3 groups:

- Group A - 111 patients using PI drugs.

- Group B - 56 patients using NPI drugs.

- Group C - 26 patients without medication.

Table 1 shows the biodemographics related to gender and age of the medication groups.

The distribution of C. albicans carriers per medication group showed no statistically significant differences (Table 2).

In the clinical intraoral examination, $18.13 \%$ (35/193) of the patients presented clinical signs of candidiasis. The erythematous form was predominant, with $60 \%(21 / 35)$ of the cases, and the pseudomembranous form represented $40 \%$ (14/35) of the cases. The clinical features of candidiasis in each group are expressed in Table 3. 
Table 1 - Biodemographics related to gender and age of the medication groups.

\begin{tabular}{|c|c|c|c|c|c|}
\hline \multicolumn{2}{|c|}{ Variable } & \multirow{2}{*}{$\begin{array}{c}\text { Group A } \\
\mathrm{N}=111 \\
82(73.87)\end{array}$} & \multirow{2}{*}{$\begin{array}{c}\text { Group B } \\
\mathrm{N}=56 \\
37(66.07)\end{array}$} & \multirow{2}{*}{$\begin{array}{c}\text { Group C } \\
N=26 \\
17(65.38)\end{array}$} & \multirow{3}{*}{$\begin{array}{c}\text { Test } \\
\text { Chi-square } \\
\chi_{2}^{2}=1.462 \\
p=0.482\end{array}$} \\
\hline \multirow{2}{*}{ Gender } & Male & & & & \\
\hline & Female & $29(26.13)$ & 19 (33.93) & 9 (34.62) & \\
\hline \multirow{3}{*}{ Age } & $\mu \pm S D$ & $40.93 \pm 9.65$ & $38.46 \pm 9.05$ & $33.42 \pm 7.39$ & \multirow{3}{*}{$\begin{array}{c}\text { ANOVA } \\
p=0.00093\end{array}$} \\
\hline & Median & 40.00 & 37.00 & 33.00 & \\
\hline & Min - Max & $20-67$ & $19-62$ & $18-46$ & \\
\hline
\end{tabular}

$\mathrm{N}=$ number of patients.

Table 2 - Distribution of C. albicans carriers per medication group.

\begin{tabular}{c|c|c|c|c}
\hline C. albicans & $\begin{array}{c}\text { Group A } \\
\mathrm{N}=111\end{array}$ & $\begin{array}{c}\text { Group B } \\
\mathrm{N}=56\end{array}$ & $\begin{array}{c}\text { Group C } \\
\mathrm{N}=26\end{array}$ & Test \\
\cline { 1 - 4 } & $62(55.85)$ & $25(44.64)$ & $14(53.85)$ & $\begin{array}{c}\text { Chi-square } \\
\chi^{2}{ }_{2}=4.034\end{array}$ \\
\hline Negative & $49(44.15)$ & $31(55.36)$ & $12(46.15)$ & $\mathrm{p}=0.133$ \\
\hline Positive & & &
\end{tabular}

$\mathrm{N}=$ number of patients.

Table 3 - Clinical features of candidiasis in each group.

\begin{tabular}{c|c|c|c|c}
\hline Clinical diagnosis & $\begin{array}{c}\text { Group A } \\
N=111\end{array}$ & $\begin{array}{c}\text { Group B } \\
N=56\end{array}$ & $\begin{array}{c}\text { Group C } \\
N=26\end{array}$ & Test \\
\cline { 1 - 3 } $\begin{array}{c}\text { Without oral } \\
\text { candidiasis }\end{array}$ & $93(83.78)$ & $46(82.14)$ & $19(73.08)$ & \\
\hline $\begin{array}{c}\text { Erythematous } \\
\text { candidiasis }\end{array}$ & $12(10.81)$ & $7(12.50)$ & $2(7.69)$ & $\begin{array}{c}\text { Chi-square } \\
\chi_{2}^{2}=6.616 \\
p=0.158\end{array}$ \\
\hline $\begin{array}{c}\text { Pseudomembranous } \\
\text { candidiasis }\end{array}$ & $6(5.41)$ & $3(5.36)$ & $5(19.23)$ & \\
\hline
\end{tabular}

$\mathrm{N}=$ number of patients.

Table 4 - Cd4 cell counts of the medication groups.

\begin{tabular}{|c|c|c|c|c|}
\hline $\mathrm{Cd} 4$ & $\begin{array}{l}\text { Group A } \\
N=111\end{array}$ & $\begin{array}{l}\text { Group B } \\
N=56\end{array}$ & $\begin{array}{c}\text { Group C } \\
N=26\end{array}$ & Test \\
\hline$\mu \pm \mathrm{SD}$ & $412.96 \pm 291.14$ & $431.61 \pm 249.38$ & $515.96 \pm 384.18$ & \multirow{3}{*}{$\begin{array}{c}\text { Anova } \\
p=0.28\end{array}$} \\
\hline Median & 357.00 & 399.50 & 511.00 & \\
\hline Min - Max & $18-1,678$ & $33-1,208$ & $16-1,924$ & \\
\hline
\end{tabular}

$\mathrm{N}=$ number of patients.

The Cd4 cell counts showed no statistically significant difference (ANOVA) among the studied groups (Table 4).

The clinical forms showed statistical differences related to Cd4 cell counts ( $\mathrm{p}=0.036$, Table 5). The Pseudomembranous form presented smaller cell counts than the erythematous form $(\mathrm{p}=0.037)$ and without lesions $(P=0.0167)$. The correlation between cd 4 cell count and the isolation of $C$. albicans was statistically significant ( $\mathrm{p}=0.046$ - $t$-test).

The relationship between the levels of $\mathrm{cd} 4$ cells and the clinical forms of candidiasis (Table 6) showed statistically significant differences $(p=0.029)$.

\section{Discussion}

Earlier studies on AIDS emphasized the prevalence of opportunistic infections, mainly oral candidiasis, in HIV-infected individuals, and observed that the clinical signs of oral candidiasis increased with the progression of the disease. ${ }^{3}$ Today, the related literature remains controversial about the reasons for the high incidence of candidiasis in HIV+ 
Table 5 - Relationship between clinical forms of candidiasis and $\mathrm{Cd} 4$ cell counts.

\begin{tabular}{c|c|c|c|c}
\hline \multirow{2}{*}{$\mathrm{Cd} 4$} & $\begin{array}{c}\text { Without oral } \\
\text { candidiasis } \\
\mathrm{N}=158\end{array}$ & $\begin{array}{c}\text { Erythematous } \\
\text { candidiasis } \\
\mathrm{N}=21\end{array}$ & $\begin{array}{c}\text { Pseudomembranous } \\
\text { candidiasis } \\
\mathrm{N}=14\end{array}$ & \multirow{2}{*}{ Test } \\
\cline { 1 - 4 } & $451.32 \pm 306.21$ & $416.33 \pm 214.58$ & $240.93 \pm 184.14$ & \multirow{2}{*}{ ANOVA } \\
\cline { 1 - 4 } Median & 399.00 & 368.00 & 174.00 & $\mathrm{p}=0.036$ \\
\cline { 1 - 3 } Min - Max & $16-1,924$ & $131-818$ & $20-542$ & \\
\hline
\end{tabular}

$\mathrm{N}=$ number of patients.

Table 6 - Levels of $\mathrm{Cd} 4$ cells and the clinical forms of candidiasis.

\begin{tabular}{|c|c|c|c|c|}
\hline $\mathrm{Cd} 4$ & $\begin{array}{l}\text { Without oral } \\
\text { candidiasis } \\
N=158\end{array}$ & $\begin{array}{l}\text { Erythematous } \\
\text { candidiasis } \\
N=21\end{array}$ & $\begin{array}{l}\text { Pseudomembranous } \\
\text { candidiasis } \\
N=14\end{array}$ & Test \\
\hline 1 & $56(35.44)$ & $8(38.10)$ & $2(14.29)$ & \multirow{3}{*}{$\begin{array}{c}\text { Chi-square } \\
\chi_{4}^{2}=10.819 \\
p=0.029\end{array}$} \\
\hline 2 & 71 (44.94) & $9(42.86)$ & $4(28.57)$ & \\
\hline 3 & 31 (19.62) & $4(19.05)$ & $8(57.14)$ & \\
\hline
\end{tabular}

$\mathrm{N}=$ number of patients.

patients. Many believed that an immune system deficiency triggered by AIDS was responsible for the severity of oral candidiasis, and not the high virulence of the yeast, since most studies had found no differences between the isolates from HIV-infected and non-infected individuals. ${ }^{17}$

The importance of candidiasis in AIDS patients led to the introduction of preventive protocols with antifungal drugs, mainly fluconazol. This may have been responsible for the selection of strains resistant to azolic derivatives. ${ }^{18}$ Another important fact is that the resistance to azolics presented by C. albicans is not evidenced in the same manner as in non-HIV patients. ${ }^{19}$

There are indications that the selection of more pathogenic strains is possible, and this possibility must not be neglected while caring for $\mathrm{HIV}^{+}$patients infected with C. albicans. Certain strains of C. albicans have a specific $\mathrm{Ca} 3$ repetitive sequence of DNA which is more frequent in individuals with AIDS when compared with samples isolated from individuals that are non-carriers of the HIV virus. ${ }^{2}$

Characterization of the differences among strains isolated from $\mathrm{HIV}+$ individuals and control groups began to increase in the 1990s. Virulence factors from C. albicans were shown to be more expressive in HIV-carrier individuals. ${ }^{20,21}$

The frequency of oral candidiasis in HIV+ patients varies among the different reports, and can af- fect up to $94 \%$ of infected individuals. However, the prevalence of candidiasis in HIV+ individuals has diminished. ${ }^{22,23}$ The data of the present study corroborate this affirmation, as the incidence of candidiasis in the present study was $18.13 \%$, which can be considered low when compared with the values of $80.1 \%$ found in the related literature. ${ }^{24}$ Many studies attribute this reduction due to the use of protease inhibitors for the treatment of patients with AIDS. , $13,25,26^{2}$

The present study was unable to make this correlation, since the incidence of $18.13 \%$ of oral candidiasis, although low, did not present statistically significant differences between the medication groups $(\mathrm{p}=0.158)$. It was expected that the patients in Group A ( $\mathrm{n}=49 / 111)$, who used PI drugs, would present a lower incidence in comparison with that of the other groups. PI also had no influence on the frequency of C. albicans isolates. When the cd4 cell count was correlated with the isolation of C. albicans, a statistically significant difference was observed between the group of colonized patients, who had a lower cd4 cell count, and the group without isolation ( $\mathrm{p}=0.046)$.

The relationship between PI drugs and a decreased frequency of oral candidiasis is credited by many authors to a direct action of the PI drugs on the yeast. ${ }^{3,16,27}$

The antifungal effect of the PI indinavir and saquinavir was demonstrated, in vitro and in vivo, at 
a minimum inhibitory concentration much higher than that attained during the conventional treatments using these drugs. ${ }^{10}$

Therapy with PI drugs has influenced not only the prevalence of oral candidiasis, but the indexes of other pathosis have also been diminished, ${ }^{1,12,28}$ in which the pathogen was not directly inhibited by the PI. This led the authors to believe that restoration of the HIV+ patient's immune system provided by the PI is the most relevant fact to be considered, during the course of treatment.

The cd4+ T lymphocyte counts showed no statistically significant differences among the medication groups. However, when the presence of candidiasis and its different clinical forms was assessed (Table 5), it was found that patients with pseudomembranous candidiasis presented a lower $\mathrm{cd} 4$ count in comparison with patients that had the erythematous form, and patients without candidiasis $(\mathrm{p}=0.036)$, evidencing the importance of the immune response with regard to this illness.

\section{References}

1. Odds FC. Candida and candidosis. $2^{\text {nd }}$ ed. London, Baillière Tindal; $1988.468 \mathrm{p}$.

2. Sullivan D, Coleman D. Candida dubliniensis: characteristics and identification. J Clin Microbiol. 1998 Feb;36(2):32934.

3. Diz Dios P, Ocampo A, Otero I, Iglesias I, Martínez C. Changes in oropharyngeal colonization and infection by Candida albicans in human immunodeficiency virus-infected patients. J Infect Dis. 2001 Jan 15;183(2):355-6.

4. Gottlieb MS, Schroff R, Schanker HM, Weisman JD, Fan PT, Wolf RA et al. Pneumocystis carinii pneumonia and mucosal candidiasis in previously healthy homosexual men: evidence of a new acquired cellular immunodeficiency. N Engl J Med. 1981 Dec 10;305(24):1425-31.

5. Korting HC, Ollert M, Georgii A, Fröschl M. In vitro susceptibilities and biotypes of Candida albicans isolates from the oral cavities of patients infected with human immunodeficiency virus. J Clin Microbiol. 1988 Dec;26(12):2626-31.

6. Torssander J, Morfeldt-Månson L, Biberfeld G, Karlsson A, Putkonen PO, Wasserman J. Oral Candida albicans in HIV infection. Scand J Infect Dis. 1987;19(3):291-5.

\section{Conclusions}

1. The frequencies of C. albicans isolates in the oral mucosa of the evaluated patients were statistically similar for the 3 medication groups.

2. $\mathrm{Cd} 4$ values were significantly lower in patients who were C. albicans carriers.

3. The frequencies of oral lesions compatible with candidiasis did not differ statistically among the medication groups.

4. The cd4 cell counts were similar for the different medication groups.

5. The cd4 cell values of the patients with pseudomembranous candidiasis were lower when compared with those of patients without lesions and with erythematous lesions.

\section{Acknowledgements}

The authors would like to thank the State of São Paulo Research Foundation (FAPESP) for the granted financial support (Proc. n. 00/01234-5).

7. Hadley S, Martinez JA, McDermott L, Rapino B, Snydman DR. Real time antifungal susceptibility screening aids management of invasive yeast infections in immunocompromised patients. J Antimicrob Chemother. 2002 Feb;49(2):415-9.

8. Zingman BS. Resolution of refractory AIDS-related mucosal candidiasis after initiation of didanosine plus saquinavir. $\mathrm{N}$ Engl J Med. 1996 Jun 20;334(25):1674-5.

9. Vargas KG, Joly S. Carriage frequency, intensity of carriage, and strains of oral yeast species vary in the progression to oral candidiasis in human immunodeficiency virus-positive individuals. J Clin Microbiol. 2002 Feb;40(2):341-50.

10. Cassone A, De Bernardis F, Torosantucci A, Tacconelli E, Tumbarello M, Cauda R. In vitro and in vivo anticandidal activity of human immunodeficiency virus protease inhibitors. J Infect Dis. 1999 Aug;180(2):448-53.

11. Murphy M, Armstrong D, Sepkowitz KA, Ahkami RN, Myskowski PL. Regression of AIDS-related Kaposi's sarcoma following treatment with an HIV-1 protease inhibitor. AIDS. 1997 Feb;11(2):261-2.

12. Grube H, Ramratnam B, Ley C, Flanigan TP. Resolution of AIDS-associated cryptosporidiosis after treatment with indinavir. Am J Gastroenterol. 1997 Apr;92(4):726. 
13. Hood S, Bonington A, Evans J, Denning D. Reduction in oropharyngeal candidiasis following introduction of protease inhibitors. AIDS. 1998 Mar 5;12(4):447-8.

14. Valdez H, Gripshover BM, Salata RA, Lederman MM. Resolution of azole-resistant oropharyngeal candidiasis after initiation of potent combination antiretroviral therapy. AIDS. 1998 Mar 26;12(5):538.

15. Deeks SG, Smith M, Holodniy M, Kahn JO. HIV-1 protease inhibitors. A review for clinicians. JAMA. 1997 Jan 8;277(2):145-53.

16. Gruber A, Speth C, Lukasser-Vogl E, Zangerle R, Borg-von Zepelin M, Dierich MP et al. Human immunodeficiency virus type 1 protease inhibitor attenuates Candida albicans virulence properties in vitro. Immunopharmacology. 1999 Apr;41(3):227-34.

17. Schmid J, Odds FC, Wiselka MJ, Nicholson KG, Soll DR. Genetic similarity and maintenance of Candida albicans strains in a group of AIDS patients demonstrated by DNA fingerprinting. J Clin Microbiol. 1992 Apr;30(4):935-41.

18. Georgopapadakou NH, Walsh TJ. Human mycoses: drugs and targets for emerging pathogens. Science. $1994 \mathrm{Apr}$ 15;264(5157):371-3.

19. Samaranayake LP, Holmstrup P. Oral candidiasis and human immunodeficiency virus infection. J Oral Pathol Med. 1989 Dec;18(10):554-64.

20. De Bernardis F, Chiani P, Ciccozzi M, Pellegrini G, Ceddia T, D’Offizzi G et al. Elevated Aspartic proteinase secretion and experimental pathogenicity of Candida albicans isolates from oral cavities of subjects infected with human immunodeficiency virus. Infect Immun. 1996 Feb;64(2):466-71.

21. Wu T, Samaranayake LP, Cao BY, Wang J. In vitro proteinase production by oral Candida albicans isolates from individuals with and without HIV infection and its attenuation by antimycotic agents. J Med Microbiol. 1996 Apr;44(4):311-6.
22. Aguirre JM, Echebarria MA, Ocina E, Ribacoba L, Montejo M. Reduction of HIV-associated oral lesions after highly active antiretroviral therapy. Oral Surg Oral Med Oral Pathol Oral Radiol Endod. 1999 Aug;88(2):114-5.

23. Margiotta V, Campisi G, Mancuso S, Accurso V, Abbadessa V. HIV infection: oral lesions, Cd4+ cell count and viral load in an Italian study population. J Oral Pathol Med. 1999 Apr;28(4):173-7.

24. Ceballos-Salobreña A, Aguirre-Urizar JM, Bagan-Sebastian JV. Oral manifestations associated with human immunodeficiency virus in a Spanish population. J Oral Pathol Med. 1996 Nov;25(10):523-6.

25. Cassone A, Tacconelli E, De Bernardis F, Tumbarello M, Torosantucci A, Chiani P et al. Antiretroviral therapy with protease inhibitors has an early, immune reconstitution-independent beneficial effect on Candida virulence and oral candidiasis in human immunodeficiency virus-infected subjects. J Infect Dis. 2002 Jan 15;185(2):188-95.

26. Korting HC, Schaller M, Eder G, Hamm G, Böhmer U, Hube B. Effects of the human immunodeficiency virus (HIV) proteinase inhibitors saquinavir and indinavir on in vitro activities of secreted aspartyl proteinases of Candida albicans isolates from HIV-infected patients. Antimicrob Agents Chemother. 1999 Aug;43(8):2038-42.

27. Hoegl L, Thoma-Greber E, Röcken M, Korting HC. Shift from persistent oral pseudomembranous to erythematous candidosis in a human immunodeficiency virus (HIV)-infected patient upon combination treatment with an HIV protease inhibitor. Mycoses. 1998 May-Jun;41(5-6):213-7.

28. Conant MA, Opp KM, Poretz D, Mills RG. Reduction of Kaposi's sarcoma lesions following treatment of AIDS with ritonavir. AIDS. 1997 Aug;11(10):1300-1. 